\title{
Charles Isenberg, 1944-1997
}

Charles Isenberg, professor of Russian literature at Reed College, died in Milford, Connecticut, on 4 December 1997, after a protracted illness. A 1966 graduate of Columbia University, he received his Ph.D. from the Department of Slavic Languages and Literatures at Harvard in 1977 with a brilliant dissertation, subsequently revised and published as Substantial Proofs of Being: Osip Mandelstam's Literary Prose (1987). In his second book, Telling Silence: Russian Frame Narratives of Renunciation (1993), he extended his interest in narrative theory and practice back into the nineteenth century through sustained analyses of Ivan Turgenev's First Love, Fedor Dostoevskii's A Gentle Creature (Krotkaia), Lev Tolstoi's "Kreutzer Sonata," and Anton Chekhov's Little Trilogy. But close analysis was not a value in itself for Isenberg; it always served as a key to larger human issues, whether psychological or cultural. He made the point himself in the concluding paragraph to his first book, where he cautions against misunderstanding Osip Mandel'shtam's tendency to give language the place more traditionally reserved for plot and character in literary prose. "Language," he insists, "is not the hero of Mandelstam's experiment. . . . His deepest concerns as a writer are not linguistic but moral. He cherished the ideal of language which he portrayed with the aid of the metaphor of 'Hellenism' because he hoped that language, understood in this way, could keep alive the tradition that humanity is called to be master in its own house" (168). The same breadth of aspiration informs the later book, with its insistence on the subtle interrelations of form and theme, and its declared hope that it might be of interest "for what it has to say about narrativity" as well as "for what it has to say about particular narratives" (viii).

Charles Isenberg taught at Wesleyan University from 1978 to 1985, and at Reed College from 1985 until his death. In 1988 he won Reed's Burlington-Northern Award for excellence in teaching. From 1992 to 1994 he was both president of the Oregon Chapter of the American Association of Teachers of Slavic and East European Languages (AATSEEL) and vice-president of the national organization. Active in the International Mandelstam Society, he was treasurer and representative of its North American chapter from 1991 on.

Isenberg held himself to the highest standards in everything he did, and he encouraged his students to do the same. Taking his role as educator seriously but not solemnly, he gave unstintingly of his time and attention. Among colleagues and friends he was convivial, bringing warmth, wit, and thoughtfulness (in both senses of the word) to all his encounters. He had an infectious sense of humor and was an inspired raconteur. His reading was humanistically broad, and his memory for what he read remarkable. There is a plain connection between his passion for skiing and sailing, and his responsiveness to the aesthetics of verbal expression, its nuances, implications, and speaking silences. He himself was an extremely skillful writer. His presence was inspiriting; his death the age of fifty-three marks a cruel loss for all who knew him, and for the profession.

DONALD FANGER

Harvard University May 1998 